\title{
ROLE OF Pseudomonas fluorescens IN INDUCED SYSTEMIC RESISTANCE FOR TOMATO VASCULAR WILT DISEASE CAUSED BY Fusarium oxysporum F. SP. LYCOPERSICI \\ El-Zahaby, H. M. \\ Agricultural Botany Department, Fac. of Agric., Tanta Univ., 31527 Egypt.
}

\section{ABSTRACT}

Using an isolate of Pseudomonas fluorescens (Pf) in biological control was found to protect tomato plants from vascular wilt disease caused by Fusarium oxysporum f. sp. lycopersici (Fol). In spite of the In vitro partially inhibition effect of $P f$ on mycelial growth of $\mathrm{Fol}$ by $47 \%$, it found that $\mathrm{Pf}$ treatment one week before inoculation can decrease the diseases severity in tomato plants by $87 \%$. These results indicating that systemic protection offered to tomato roots by the Pf for vascular wilt disease caused by Pol infection and explaining that ISR is involved.

Induction of defense enzymes by $P f$ against challenge inoculation with $\mathrm{Fol}$ in tomato was studied. Activities of phenylalanine ammonia-lyase (PAL), peroxidase (POX) and polyphenol oxidase (PPO) increased in bacterized tomato root tissues challenged with the pathogen. Analysis revealed that a PAL, POX and PPO were expressed at higher levels in bacterized tomato root tissues challenge inoculated with the pathogen. Activities of PAL and POX reached maximum at the $4^{\text {th }}$ day while, activity of PPO reached maximum at the $6^{\text {th }}$ day after challenge inoculation. Induction of these enzymes activities was found, not only in Pf treated root tissues challenged with the pathogen, but also in roots treated with $\mathrm{Pf}$ alone. These results suggest that induction of defense enzymes involved in phenylpropanoid pathway might have contributed to restriction of invasion of $\mathrm{Fol}$ in tomato plants.

Keywords: Fusarium oxysporum f. sp. lycopersici, induced systemic resistance, Lycopersicum esculentum, plant growth-promoting rhizobacteria, Pseudomonas fluorescens.

\section{INTRODUCTION}

Vascular wilt disease of tomato (Lycopersicon esculentum Mill.) caused by Fusarium oxysporum f. sp. Iycopersici (Sacc.) W.C. Snyder \& H.N. Hansen $(F o l)$ is one of the most economically important and widespread diseases of the cultivated tomato (Reis et al., 2005).

Environmental hazards and health concerns, associated with the use of chemical pesticides have resulted in an increasing interest in biological control as a promising alternative or a supplemental way of reducing the use of pesticides. Biological control involving the use of such plant beneficial microorganisms for plant protection such as bacteria and fungi, which naturally occurring in soil, is being considered as a viable substitute to reduce the use of chemical pesticides (Compant et al., 2005).

For over 100 years, scientists and naturalists have observed that when plants survive pathogen infection they develop an increased resistance to subsequent infections. In 1933, Chester reviewed 200 publications describing a phenomenon he termed physiological acquired immunity (Chester, 1933). In 1961, Ross demonstrated, in tobacco plants, that infections of TMV were restricted by a prior infection. This resistance was effective against not only 
TMV but also tobacco necrosis virus and certain bacterial pathogens. Ross coined the term "systemic acquired resistance" (SAR) to refer to the inducible systemic resistance (Ross, 1961).

Root-colonizing bacteria that have a beneficial effect on plants are termed plant growth-promoting rhizobacteria (PGPR) (Kloepper and Schroth, 1978). In the biological control of soil borne diseases of plants there is a form of induced resistance associated with the colonization of plant roots by certain PGPR, referred to as "induced systemic resistance" (ISR) (van Loon et al., 1998). Results of several investigators showed that ISR is like to SAR in effective against a broad range of diseases caused by viruses, bacteria, and fungi (Wei et al., 1996; van Loon et al., 1998; Raupach and Kloepper, 1998, 2000; Murphy et al., 2000; Nandakumar et al., 2001; Zehnder et al., 2001 and Niranjan Raj et al., 2003).

Treatment with PGPR and fungi have been reported to sensitize plants to defend themselves against pathogen attack by triggering various defense mechanisms including production of phytoalexins, synthesis of phenolics (M'Piga et al., 1997 and Chen et al., 2000), accumulation of pathogenesisrelated proteins (Meena et al., 1999). The defense gene products peroxidases (POX) and polyphenol oxidases (PPO) catalyze the formation of lignin and phenylalanine ammonia-lyase (PAL) is involved in the synthesis of phytoalexins and phenolics (Karthikeyan et al., 2005).

Pseudomonas spp. can induce systemic biochemical and ultra structural changes in the roots that lead to a greater ability of the host plant to defend itself against root infecting pathogens. The use of Fluorescent pseudomonads for controlling soil borne plant diseases has been well documented (Weller and Cook, 1986 and Sarma et al., 2000).

Fluorescent Pseudomonas spp. are among the most effective rhizosphere bacteria in reducing soil-born diseases in disease-suppressive soils (Weller, 1988). These bacteria can antagonize soil borne pathogens through various mechanisms (cf. van Loon et al., 1998). However, Wei et al., (1991) suggested that ISR mediated by Pseudomonas spp. in several plant diseases interactions; neither competition nor antibiosis is involved in disease suppression.

The present study was carried out to assess the mode of action of nonpathogenic plant growth promoting rhizobacteria (PGPR) Pseudomonas flourescens in the management of Fusarium vascular wilt disease of tomato. The induction of defense enzymes related to the phenylpropanoid pathway known to be involved with induced systemic resistance such as phenylalanine ammonia-lyase, peroxidase and polyphenol oxidase in tomato vascular wilt disease caused by Fusarium oxysporum f. sp. lycopersici in response to application by PGPR biocontrol agent, P. fluorescens was investigated.

\section{Pathogen isolation:}

\section{MATERIALS AND METHODS}

Naturally infected tomato plants showing wilt symptoms were obtained in April 2006 from a commercial field growing in Tanta district, El-Gharbia Governorate, Egypt. Isolation procedures of the causal pathogen were 
carried out from infected roots. After washing in running tap water, surface sterilized with $1 \%$ sodium hypochlorite solution for two minutes and rinsed three times in sterilized water, then dried between sterilized filter papers. Small pieces were placed on potato dextrose agar medium (PDA) supplemented with $300 \mathrm{mg}$ of streptomycin sulfate/L in Petri-dishes and incubated at $25 \pm 2^{\circ} \mathrm{C}$. Pure culture was obtained using single spore technique and maintained on PDA at $27^{\circ} \mathrm{C}$. Isolated pathogen was preliminary identified as Fusarium oxysporum according to Booth (1971 \& 1977) and Nelson et al. (1983) and confirmed as F. oxysporum f. sp. lycopersici ( $F o l$ by Agricultural Botany Department, Faculty of Agriculture, Kafr El-Shikh University.

Inoculum Preparation and Inoculation:

Fol isolate was grown on PDA plates for two weeks. Conidia were removed from the media surface by pipetting $10 \mathrm{ml}$ of sterile saline onto the plates and gently scraping the conidia off the media surface by using a sterile spatula. The conidia were then separated from mycelium fragments by pouring the suspension through a sterile piece of gauze into a sterile beaker. The concentration of conidia was adjusted to $10^{8}$ conidia/ml with a hemocytometer.

Inoculation was performed by dipping the root ball of the seedlings during transplanting into the conidial suspension in a $500 \mathrm{ml}$ beaker for 5 minutes. Roots were dipped for 5 minutes in a beaker containing a sterile saline without conidia for non-inoculated control treatment. After inoculation, plants were planted in $25-\mathrm{cm}$ diameter plastic pots containing sterilized sandy soil, ten plants each.

\section{Plant growth promoting rhizobacterium (PGPR):}

The bacterial antagonistic agent Pseudomonas fluorescens $(P f)$ isolate as PGRP were obtained from the laboratory of Prof. Z. Klement, Department of Pathophysiology, Plant Protection Institute, Budapest, Hungary. The isolate was maintained on King's B (KB) medium (King et al., 1954), and routinely subcultured. Some slants were maintained at $4^{\circ} \mathrm{C}$, and the cultures were grown at $27^{\circ} \mathrm{C}$. Culture of $P f$ was grown for $24 \mathrm{hr}$. at $27^{\circ} \mathrm{C}$ and harvested by washing the culture with sterile saline by using a sterile spatula. Cell concentration was adjusted to an optical density of 0.06 at $660 \mathrm{~nm}$ which was equal to $10^{8} \mathrm{cfu}$. $\mathrm{ml}^{-1}$.

Tomato plants bacterization:

Bacterization was performed into the seedling's flat pots with $200 \mathrm{ml}$ of the Pf cell suspension/pot. Pots of control treatment were drenched with only sterile saline and maintained.

\section{Plant materials:}

Tomato cultivar Castle Rock which susceptible to Fusarium wilt, was used in this study. Seeds were surface sterilized by immersion in $1 \%$ sodium hypochlorite for $20 \mathrm{~min}$ and rinsed three times in sterile distilled water, and sown in a flat $25 \times 40 \mathrm{~cm}$ pots contained autoclaved sandy soil and grown in a greenhouse at $22 \pm 2{ }^{\circ} \mathrm{C}$. After 3 weeks, one set of the seedling's flat pot was bacterized with the $\mathrm{Pf}$ as described above. Another one week later, uniform seedlings were transplanted in $25-\mathrm{cm}$ diameter plastic pots containing sterilized sandy soil. Inoculation with Fol was made during transplanting. The 
experimental plots were made of four pots with ten plants each. They were watered daily and fertilized twice a week with a standard nutrient solution according to Pharand et al. (2002).

\section{Disease severity:}

Disease symptoms were recorded every 3 days for three weeks after inoculation. Disease severity (DS) evaluation was based on the leaf, vascular discoloration and wilting using 0-4 scale according to Kesevan and Chounhury, 1977 (cf. Özgönen et al., 2001). The scale used was: $0=$ no wilting symptoms; 1 = plant slightly wilted, vascular discoloration only in main root region; 2 = plant moderately wilted, yellowing of old leaves, spreading of vascular browning; 3 = plant severely wilted, dying of all leaves except end leaves and $4=$ dead plant, seedling entirely wilted. The disease severity was calculated using disease scale values.

Disease severity was determined using the following equation (Song et al., 2004):

Disease severity $(\%)=\frac{(\Sigma \text { Scale } \times \text { number of plants infected })}{(\text { Highest scale } \times \text { total number of plants })} \times 100$

Ten plants per treatment were used and variance analysis of the treatment effect on measured data was performed.

In vitro antagonistic effect of $P$. fluorescens on the $F$. oxysporum f. sp. lycopersici:

A disc (5-mm-diameter) carrying mycelium of $\mathrm{Fol}$ was taken from the end margin of 7-day-old culture, and placed at the centre of a $9 \mathrm{~cm}$ diameter PDA plate between two parallel streaks of $P$. fluroscencs which were $6 \mathrm{~cm}$ apart. Plates with the fungal disc and without bacterial streaks were served as control. When the fungal growth of the control approached the edge of the plates, antagonistic effect was assessed by relating mycelial diameters on plates inoculated with bacteria to mycelial diameter on control plates and percentage inhibition were calculated. Data from ten plates were used for this calculation.

\section{Biochemical analysis:}

Sampling was carried out at $0,2,4,6,8,10,12$ and $14 \mathrm{~d}$ after inoculation. A replicate of 3 plants were uprooted each time. Roots were washed thoroughly with tap water, dried with filter paper, and cut with scissors. From each sample, one gm frozen in liquid nitrogen, ground in a precooled mortar and pestle, suspended in $3 \mathrm{ml}$ cold $0.1 \mathrm{M}$ potassium phosphate buffer $(\mathrm{pH} 7.2)$ containing $2 \%$ polyvinylpolypyrrolidone (PVPP) and $0.1 \mathrm{mM}$ EDTA. The homogenate was centrifuged at $8,000 \times \mathrm{g}$ for 20 minutes. The supernatant was used for determination of PPO and POX enzymes activity. For PAL determination, samples were homogenized in $3 \mathrm{ml}$ of ice-cold $0.1 \mathrm{M}$ sodium borate buffer $(\mathrm{pH} 7.0)$, and the same proceeding was conducted.

Phenylalanine Ammonia-lyase (PAL) activity:

Activity of PAL (EC 4.3.1.5) was determined as the rate of conversion of L-phenylalanine to trans-cinnamic acid as described by Dickerson et al. 
(1984). A sample containing $0.4 \mathrm{ml}$ of enzyme extract was incubated with 0.5 $\mathrm{ml}$ of $0.1 \mathrm{M}$ borate buffer, $\mathrm{pH} 8.8$, and $0.5 \mathrm{ml}$ of $12 \mathrm{mM} \mathrm{L}$-phenylalanine in the same buffer for $30 \mathrm{~min}$ at $30^{\circ} \mathrm{C}$. The optical density value was recorded at $290 \mathrm{~nm}$ and the amount of trans-cinnamic acid formed calculated using its extinction coefficient of $9.63 \mathrm{mM}^{-1} \mathrm{~cm}^{-1}$ (Dickerson et al., 1984). Enzyme activity was expressed as $\mu \mathrm{mol}$ trans-cinnamic acid $\mathrm{min}^{-1}$ per gram fresh weigh.

\section{Peroxidase (POX) activity:}

Activity of POX (EC 1.11.1.7) was determined spectrophotometrically according to Zheng and van Huystee (1992). The reaction mexture (4ml) contained $10 \mathrm{mM}$ sodium phosphate buffer $(\mathrm{pH} 6), 3.8 \mathrm{mM} \mathrm{H}_{2} \mathrm{O}_{2}$ as a substrate, $20 \mathrm{mM}$ guaiacol, and $0.2 \mathrm{ml}$ plant extract. After incubation at $30^{\circ} \mathrm{C}$ for $10 \mathrm{~min}$, the assay was determined by following the increase of absorbance at $470 \mathrm{~nm}$. (extinction coefficient $=26.6 \mathrm{mM}^{-1} \mathrm{~cm}^{-1}$ ). Peroxidase activity was expressed as unit $\mathrm{min}^{-1}$ per gram fresh weigh.

\section{Polyphenol oxidase (PPO) activity:}

Activity of PPO enzyme ((EC 1.14.18.1) was measured spectrophotometrically by determining the decrease of the absorbency of yellow-color duo to the oxidation of Catichol at $495 \mathrm{~nm}$. (Sadasivam and Manickam, 1992). The reaction mixture was $2.4 \mathrm{ml}$ of $0.1 \mathrm{M}$ Phosphate buffer $(\mathrm{pH}$ 6.5), $3 \mathrm{ml}$ of Catichol solution $(10 \mathrm{mM})$ and $0.3 \mathrm{ml}$ plant extract. Changes in absorbance was recorded every $30 \mathrm{sec}$ up to $5 \mathrm{mn}$. Calculation of the activity was carried out and illustrated as unit $\min ^{-1}$ per gram fresh weigh.

\section{Experimental treatments:}

The study was conducted with 4 treatments of tomato plants as follow: (i) inoculation with F. oxysporum f. sp. Lycoprcisi, (ii) bacterization of plants by $P$. fluorescens, (iii) bacterization by $P$. fluorescens and inoculation with $F$. oxysporum f. sp. Lycoprcisi and (iv) neither infested with Fol nor bacterized with $\mathrm{Pf}$ as absolutely control treatment. Each treatment was replicated three times.

\section{Statistical analysis:}

All the data were analyzed by analysis of variance (ANOVA) with factorial treatment structure. When $F$ values were significant at $p>0.05$, differences among the treatments were determined by Student test.

\section{RESULTS}

\section{Isolation and identification of the causal pathogen:}

Fungal isolate were isolated from naturally diseased tomato plants and showing wilt symptoms and identified as Fusarium oxysporum according to Booth (1971 \& 1977) and Nelson et al. (1983) and confirmed as $F$. oxysporum f. sp. lycopersici by Agricultural Botany Department, Faculty of Agriculture, Kafr El-Shikh University.

\section{Effect of PGPR ( $P$. fluorescens) on Disease severity:}

By applying Pf one week before inoculation with the Fol pathogen, disease incidence was significantly lower than inoculated and unbacterized treatment. Results showed that disease severity was $13.33 \%$, however inoculated and not bacterized treatment recorded 83.3\% (Fig 1). 
In vitro antagonistic effect of $P$. fluorescens on the $F$. oxysporum f. sp. lycopersici radial growth:

$P$. fluorescens was inhibited mycelial growth of $F o l$ in vitro. Results obtained (Fig. 2) show that inhibition of Fol by $47 \%$. Indeed, the use of Pf partially halted mycelial growth of Fol significantly.

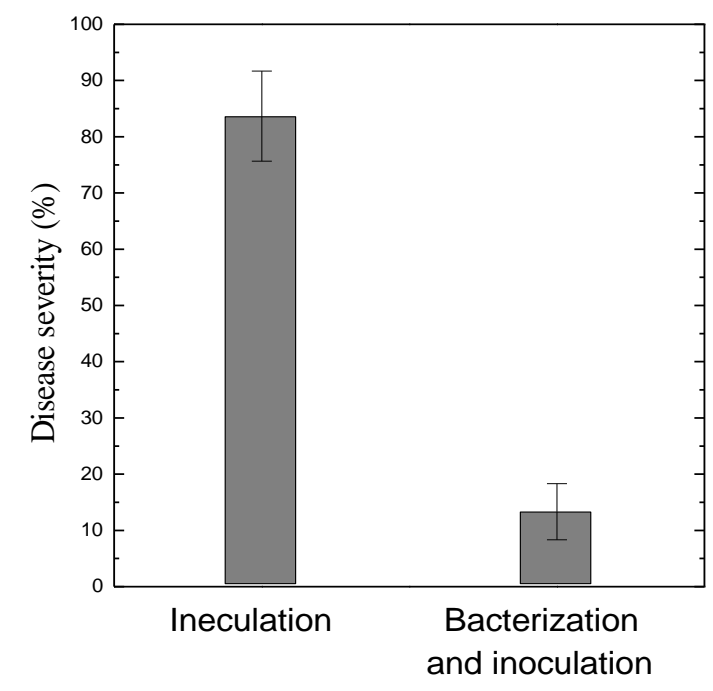

Fig. 1. Disease incidence of tomato plants inoculated with $F$. oxysporum f. sp. lycopersici and bacterization with Pseudomonas fluorescens one week before the inoculation.

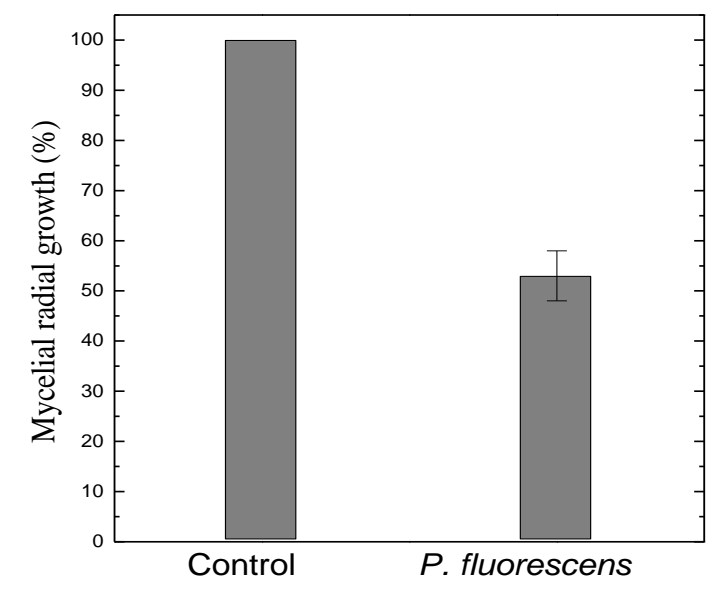

Figure 2. Effects of Pseudomonas fluorescens application in vitro on the mycelial radial growth of Fusarium oxysporum f.sp lycopersici. 
Enzyme activities:

Activity of phenylalanine ammonia-lyase (PAL) (EC 4.3.1.5):

$P$. fluroscencs as a PGPR induced significant activity of PAL in the treated tomato roots over the period of time, however, in the untreated plants did not show any change in the pattern of PAL production (Fig. 3).

In the challenge-inoculated plants by Fol, the enzyme induction was highest on 4 days after challenge. Non-bacterized plants showed slightly higher activity of PAL upon challenge. The increase was significant compared to control on the $4^{\text {th }}$ day of challenge.

There was highly significant increase in induction of PAL in the bacterized tomato leaves compared to the untreated. Even though the level started gradually declining after reaching a peak on $4^{\text {th }}$ day, there was significantly increased activity of the enzyme by PGPR even on $14^{\text {th }}$ day of bacterization. The highest activity of PAL upon inoculation by $\mathrm{Fol}$ was observed in the non- bacterized plants, which was significantly different than the bacterial treated plants. For all treatments, the peak was on the $4^{\text {th }}$ day of challenge and then started diminishing.

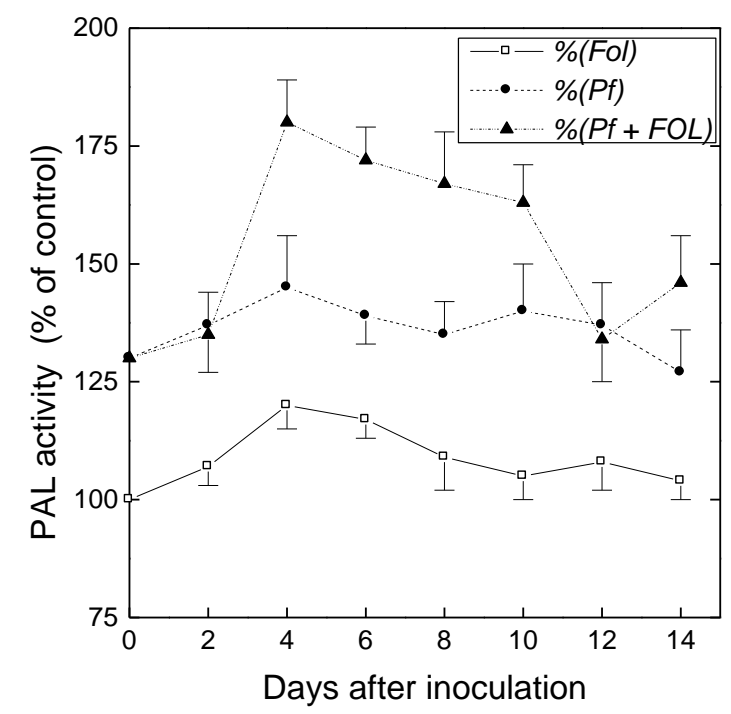

Figure 3. Phenylalanine ammonia-lyase (PAL) activity in roots of tomato plants cv. Castle Rock inoculated with Fusarium oxysporum f.sp lycopersici, bacterized by Pseudomonas fluorescens and challenged inoculation one week after bacteriazation. The PAL activity in the control plants was $4.8 \pm 0.5 \mu \mathrm{mol}$ trans-cinnamic acid $\mathrm{g}^{-1} \mathrm{FW} \mathrm{min}^{-1}$. Means of three replicates are shown. 
Activity of peroxidase (POX) (EC 1.11.1.7)

Activity of POX was increased significantly over time upon root bacterization (Fig. 4). Significantly higher activity was observed on the bacterization treatment. There maintained a higher level of POX in bacterized roots than in the non-bacterized. In the challenge inoculated plants, pathogen elicitors increased the POX level in tomato roots and a maximum level was reached on $4^{\text {th }}$ day of challenge. All the treatments showed the highest peak on $4^{\text {th }}$ day. The increase in enzyme activity induction was only significant in the $4^{\text {th }}$ day in inoculated and non-bacterized plants. POX level diminished uniformly in all treatments immediately after $4^{\text {th }}$ day of challenge.

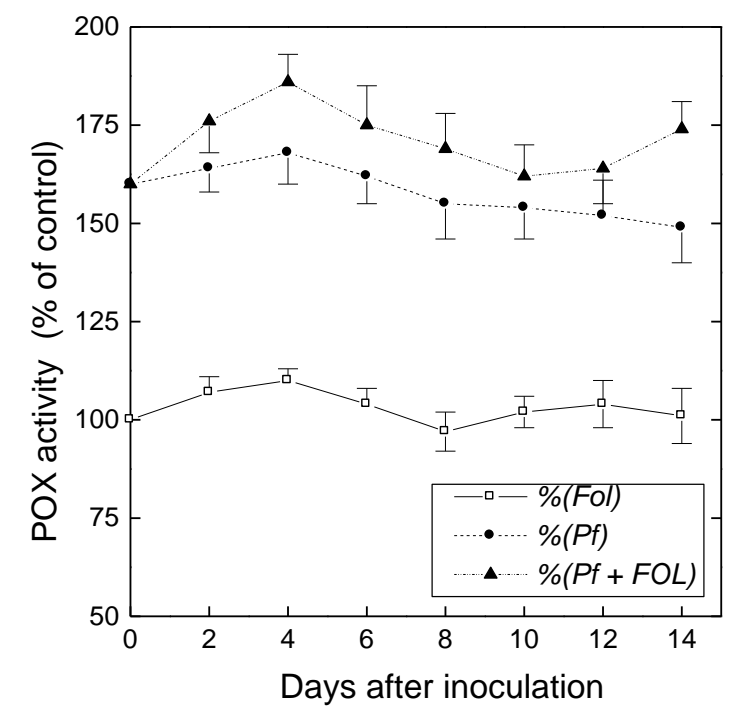

Figure 4. Peroxidase (POX) activity in roots of tomato plants cv. Castle Rock inoculated with Fusarium oxysporum f.sp lycopersici, bacterized by Pseudomonas fluorescens and challenged inoculation one week after bacteriazation. The POX activity in the control plants was $7.2 \pm 0.8 \mu u n i t \mathrm{~g}^{-1} \mathrm{FW} \mathrm{min}^{-1}$. Means of three replicates are shown.

Activity of polyphenoloxidase (PPO) (E.C. 1.14.18.1):

Activity of PPO reached the highest peak in a later stage unlike the other two enzymes studied. The PPO activity upon bacterization of the tomato roots occurred only on the $6^{\text {th }}$ day after inoculation (Fig. 5). Untreated plants did not show any significant fluctuations in PPO activity in the study period. PGPR maintained the PPO activity in a significantly higher level throughout. Even in the plants, which were challenge inoculated after bacterization, there was an increase in the PPO level in roots compared to the control. 


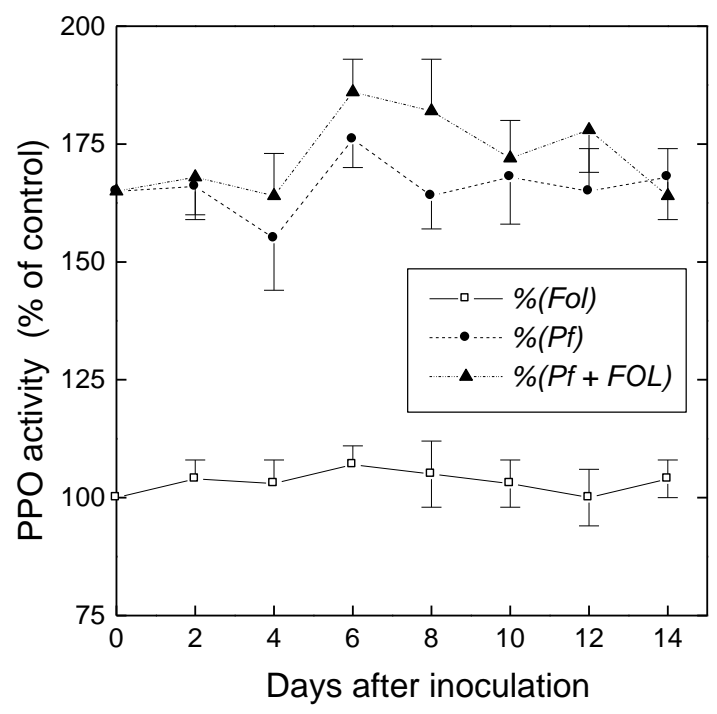

Figure 5. Polyphenoloxidase (PPO) activity in roots of tomato plants cv. Castle Rock inoculated with Fusarium oxysporum f.sp lycopersici, bacterized by Pseudomonas fluorescens and challenged inoculation one week after bacteriazation. The PPO activity in the control plants was $9.6 \pm 0.9 \mu$ unit $^{-1} \mathrm{FW}$ $\mathrm{min}^{-1}$. Means of three replicates are shown.

\section{DISCUSSION}

Induced Systemic resistance (ISR) is potentiated by plant growthpromoting rhizobacteria (PGPR), of which the best characterized are strains within several species of Pseudomonas that cause no visible damage to the plant's root system (reviewed in van Loon et al., 1998). As PGPR, $P$. fluorescens $(P f)$ has been demonstrated to induce systemic resistance for different diseases (Wei et al, 1991; Maurhofer et al, 1994 and Liu et al, 1995).

Results obtained (Fig 2), indicated that In Vitro test of Pf caused partially reduction of radial growth of $\mathrm{Fol}$ pathogen (47\%). While, results illustrated in Fig. 1 showed that in greenhouse experiment, more significantly decreased of vascular wilt disease severity (87\%) was obtained with Pf application. These results explained that, not only antagonistic effect of $P f$ for Fol control on tomato plants, but there is an ISR involved in this reaction. Bakker et al. (2007) reviewed that several investigators were obtained similar results.

In the present study, when tomato roots were bacterized with $P f$ there are some induced defence enzymes which in turn reflected in the reduced wilt symptoms when plants were challenge inoculated with the vascular wilt 
pathogen Fol. Tomato roots showed increased synthesis of PAL, POX and PPO. Similar results of elevated levels of PAL, POX and PPO have been reported in cucumber plants infected with Pythium aphanidermatum and treated with PGPR strains (Chen et al., 2000).

The induction of defence related enzymes by PGPR treatment was correlated with the percentage vascular wilt suppression in the bacterized plants upon challenge inoculation with the fungal pathogen, Fol. The first enzyme of phenyl propanoid metabolism pathway is PAL, that catalyzes the trans-elimination of ammonia from L-phenyl alanine to form trans cinnamic acid which in turn enter different biosynthetic pathways leading to lignin (Hahlbrock and Grisebach, 1975). Increase in the PAL activity which observed in this study explains that the ISR in tomato plants bacterized Pf may be related to biosynthesis of lignin originate from L-phenyl alanine. Similar results were obtained by many investigators in several crops (Anderson and Guerra, 1985; van Peer et al, 1991; Daayf et al, 1997; Podile and lami, 1998 and Meena et al, 1999).

The present study revealed some increase in the POX activity due to $P f$ treatment and continues to be synthesized throughout the study period. POX is involved in lignification leading to disease resistance (Lagrimini et al, 1987). For lignification, specific cell wall peroxidases are thought to be required to generate $\mathrm{H}_{2} \mathrm{O}_{2}$ (Van Huystee, 1987). Polymerization of cinnamyl alcohols to lignin is catabolised by POX (Harkin and Obst, 1973). This is in agreement with Nandakumar et al. (2001), who published that ISR in rice has been correlated with an increase in activity of pathogenesis related peroxidase in PGPR treated plants inoculated with the rice sheath pathogens, Rhizoctonia solani.

The use of PGPR strains seems to be environmentally benign relative to current pesticides. These characteristics make ISR an attractive approach for managing crop pests in a sustainable manner within the scope of a conventional agriculture system. (Vallad and Goodman, 2004). P. fluorescence are capable to inducing higher levels of defence enzymes such as PAL, POX and PPO in tomato roots and it could be speculated that induced enzyme activities by Pf may be associated with the bio-synthesis of phenolic compounds and lignin that have been considered as major determinants in ISR against the vascular wilt disease. Further studies have to be performed on the ISR by PGPR to find out the exact signaling molecules involved in Pf mediated ISR in tomato plants.

\section{REFERENCES}

Anderson, A.J. and D. Guerra (1985): Responses of bean to root colonization with Pseudomonas putida in a hydroponic system. Phytopathology 75(9): 992-995.

Bakker, P.A.H.M.; C.M.J. Pieterse, and L.C. van Loon (2007): Induced systemic resistance by Fluorescent Pseudomonas spp. Phytopathology, 97(2): 239-243. 
Booth, C. (1971): The Genus Fusarium. Commonwealth Agricultural Bureaux, Farnham Royal, Bucks, England, $237 \mathrm{p}$.

Booth, C. (1977): Fusarium: Laboratory Guide to the Identification of the Major Species. Commonwealth Agricultural Bureaux, Farnham Royal, Bucks, England, $58 \mathrm{p}$.

Chen, C.; R.R. Bélanger; N. Benhamou and T.C. Paulitz (2000): Defence enzymes induced in cucumber roots by treatment with plant growthpromoting rhizobacteria (PGPR) and Pythium aphanidermatum. Physiol. Mol. Plant pathol. 56(1): 13-23.

Chester, K.S. (1933): The problem of acquired physiological immunity in plants. Q. Rev. Biol. 8: 275-324.

Compant, S.; B. Duffy; J. Nowak; C. Clément and E.A. Barka (2005): Use of plant growth-promoting bacteria for biocontrol of plant diseases: Principles, mechanisms of action and future prospects. Appl. and Environ. Microbio. 71(9): 4951-4959.

Daayf, F.; R. Bel-Rhlid and R.R. Bélanger (1997): Methyl ester of p-coumaric acid: a phytoalexin-like compound from long English cucumber leaves. J. Chem. Ecol. 23(6): 1517-1526.

Dickerson, D.P.; S.F. Pascholati; A.E. Hagerman; L.G. Butler and R.L. Nicholson (1984): Phenylalanine ammonia-lyase and hydroxy cinnamate: CoA ligase in maize mesocotyls inoculated with Helminthosporium maydis or Helminthosporium carbonum. Physiol. Plant Pathol. 25: 111-123.

Hahlbrock, K. and H. Grisebach (1975): The flavonoids. In: J. B. Harbourne; T. J. Mabry and H. Mabry (eds). Chapman \& Hall, London. pp. 866915.

Harkin, J.M. and J.R. Obst (1973): Lignification in trees: indication of exclusive peroxidase participation. Science 180: 296-298.

Karthikeyan, M.; V. Jayakumar; K. Radhika; R. Bhaskaran; R. Velazhahan and D. Alice (2005): Induction of resistance in host against the infection of leaf blight pathogen (Alternaria palandui) in onion (Allium cepa var aggrigatum). Indian J. Biochem. Biophys. 42(6): 371-377.

Kesevan, V. and B. Chounhury (1977): Screening for resistance to Fusarium wilt of tomato. Sabrao Journal 9(1): 57-65.

King, E.O.; M.K. Ward and D.E. Raney (1954): Two simple media for the demonstration of pyocyanin and fluorescein. J. Lab. Clin. Medic. 4: 301-307.

Kloepper, J.W. and M.N. Schroth (1978): Plant growth-promoting rhizobacteria on radishes. Proc. Int. Conf. Plant Pathogenic Bacteria, $4^{\text {th }} \cdot 2: 879-882$.

Lagrimini, L.M.; W. Burkhart; M. Moyer and S. Rothstein (1987): Molecular cloning of complementary DNA encoding the lignin forming peroxidase from tobacco: molecular analysis and tissue specific expression. Proc. Nat. Acad. Sci. USA. 84(21): 7542-7546.

Liu, L.; J.W. Kloepper and S. Tuzun (1995): Induction of systemic resistance in cucumber by plant growth-promoting rhizobacteria: duration of protection and effect of host resistance on protection and root colonization. Phytopathology 85: 1064-1068. 
M'Piga, P.; R.R. Bélanger; T.Z. Paulitz and N. Benhamou (1997): Increased resistance to Fusarium oxysporum f. sp. radicis-lycopersici in tomato plants treated with the endophytic bacterium Pseudomonas fluorescence, strain 63-28. Physiol. Mol. Plant pathol. 50(5): 301-320.

Maurhofer, M.; C. Hase; P. Meuwly; J.-P. Métraux and G. Défago (1994): Induction of systemic resistance of tobacco, to tobacco necrosis virus by the root-colonizing Pseudomonas fluorescence strain $\mathrm{CHAO}$ : influence of the gacA gene and of pyoverdine production. Phytopathology 84(2): 139-146.

Meena, B.; R. Radha Jayalskhmi; P. Vidhyasekharan and R. Velazhakan (1999): Effect of foliar application Pseudomonas fluorescence on activities of phenylalanine ammonia-lyase, chitinase and 1,3gluconase and accumulation of phenolics in rice. Acta-Phytopathol Entomol. Hung. 34: 307-315.

Murphy, J.F.; G.W. Zehnder; D.J. Schuster; E.J. Sikora; J.E. Polston and J.W. Kloepper (2000): Plant growth-promoting rhizobacterial mediated protection in tomato against tomato mottle virus. Plant Dis. 84(7): 779784.

Nandakumar, R.; S. Babu; R. Viswanathan; T. Raguchander and R. Samiyappan (2001): Induction of systemic resistance in rice against sheath blight disease by Pseudomonas fluorescence. Soil boil. Biochem. 33: 603-612.

Nelson, P.E.; T.A. Toussoun; and W.F.O. Marasas (1983): Fusarium Species: An Illustrated Manual for Identification. Pennsylvania State University, University Park, 193p.

Niranjan Raj, S.; G. Chaluvaraju; K.N. Amruthesh; H.S. Shetty; M.S. Reddy and J.W. Kloepper (2003): Induction of growth promotion and resistance against downy mildew on pearl millet (Pennisetum glaucum) by rhizobacteria. Plant Dis. $87(4)$ : 380-384.

Özgönen, H.; M. Bicici and A. Erkilic (2001): The effect of salicyclic acid and endomycorrhizal fungus Glomus etunicatum on plant development of tomatoes and Fusarium wilt caused by Fusarium oxysporum f.sp lycopersici. Turk. J. Agric. 25: 25-29.

Pharand, B.; O. Carisse and N. Benhamou (2002): Cytological aspects of compost-mediated induced resistance against Fusarium crown and root rot in tomato. Phytopathology 92: 424-438.

Podile, R. and V.D.V. Lami (1998): Seed bacterization with Bacillus subtilis, AF1 increases PAL and reduces the incidence of Fusarium wilt in Pigeon pea. J. Phytopathology 146: 255-259.

Raupach, G.S. and J.W. Kloepper (1998): Mixtures of plant growth-promoting rhizobacteria enhance biological control of multiple cucumber pathogens. Phytopathology 88: 1158-1164.

Raupach, G.S. and J.W. Kloepper (2000): Biocontrol of cucumber diseases in the field by plant growth-promoting rhizobacteria with and without methyl bromide fumigation. Plant Dis. 84(10): 1073-1075. 
Reis, A.; H. Costa; L.S. Boiteux and C.A. Lopes (2005): First report of Fusarium oxysporum f. sp. Iycopersici race 3 on tomato in Brazil. Fitopatologia Brasileira 30: 426-428.

Ross, A. F. (1961): Systemic acquired resistance induced by localized virus infections in plants. Virology 14: 340-358.

Sadasivam, S. and A. Manickam (1992): Biochemical Methods for Agricultural Sciences. Wiley Eastern Ltd., New Delhi, India, 246p.

Sarma, Y.R.; P.P. Rajan; N. Beena; Diby Paul and M. Anandaraj (2000): Role of rhizobacteria on disease suppression in spice crops and future prospects. Seminar on biological control and plant growth promoting rhizobacteria (PGPR) for sustainable agriculture, Dept. of Biosciences, School of Life Sciences, University of Hyderabad. Abstract, 01-37.

Song, W.; L. Zhou; C. Yang; X. Cao; L. Zhang and X. Liu (2004): Tomato Fusarium wilt and its chemical control strategies in a hydroponic system. Crop Protection 23: 243-247.

Vallad, G.E. and R.M. Goodman (2004): Systemic acquired resistance and induced systemic resistance in conventional agriculture. Crop Sci. 44: 1920-1934.

van Huystee, R.B. (1987): Some molecular aspects of plant peroxidases: Biosynthetic studies. Annual Review of Plant Physiology. 38: 205-219.

van Loon, L.C.; P.A.H.M. Bakker, and C.M.J. Pieterse (1998): Systemic resistance induced by rhizosphere bacteria. Ann. Rev. Phytopathol. 36: 453-483.

van Peer, R.; G.J. Niemann and B. Schippers (1991): Induced resistance and phytoalexin accumulation in biological control of Fusarium wilt of carnation by Pseudomonas sp. strain WCS417r. Phytopathology 81: 728-734.

Wei, G.; J.W. Kloepper and S. Tuzun (1991): Induction of systemic resistance of cucumber to Colletotrichum orbiculare by select strains of plant growth promoting rhizobacteria. Phytopathology 81(12): 1508-1512.

Wei, G.; J. W. Kloepper and S. Tuzun (1996): Induced systemic resistance to cucumber diseases and increased plant growth by plant growthpromoting rhizobacteria under field conditions. Phytopathology 86(2): 221-224.

Weller, D.M. (1988): Biological control of soil-borne plant pathogens in the rhizosphere with bacteria. Annual Review of Phytopathol. 26: 379407.

Weller, D.M. and R.J. Cook (1986): Increased growth of wheat by seed treatment with fluorescent Pseudomonads, and implication of Pythium control. Can. J. Plant Pathol. 8(3): 328-334.

Zehnder, G.W.; J.F. Murphy; E.J. Sikora and J.W. Kloepper (2001): Application of rhizobacteria for induced resistance. Eur. J. Plant Pathol. 107: 39-50.

Zheng, X. and R.B. van Huystee (1992): Peroxidase-regulated elongation of segments from peanuts hypocotyls. Plant Science 81: 47-56. 


\section{El-Zahaby, H. M.}

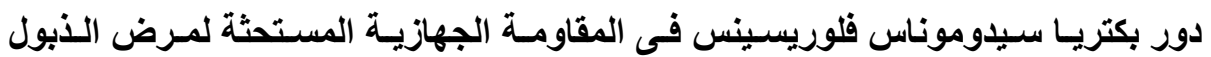

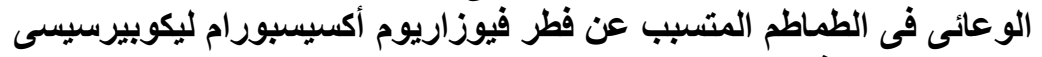

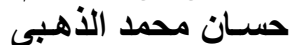
قسم النبات الزراعى ، كلية الزراعة بطنطا ، جامعة طنطا VY P ا T جمهورية مصر العربية. وجد أن عزلة من بكتريا سيدوموناس فلوريسينس (Pf) في حالـة إستخدامها للمكافحسة

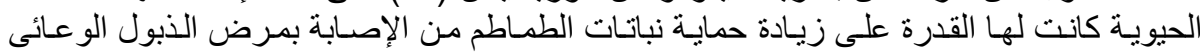

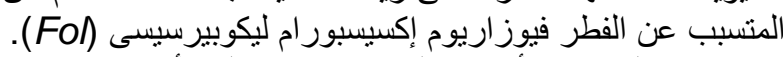

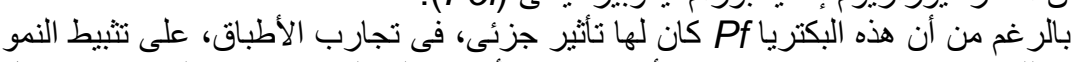

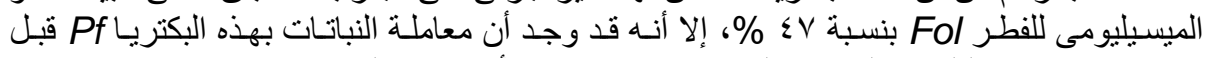

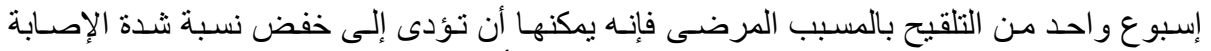

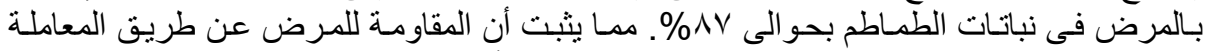

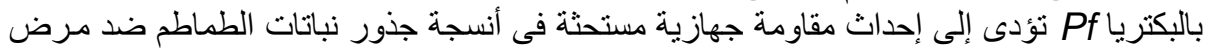

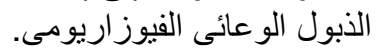

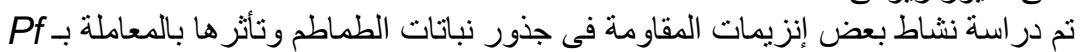

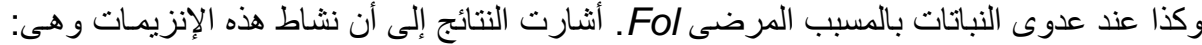

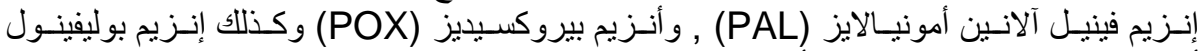

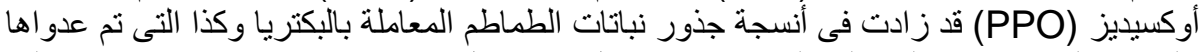

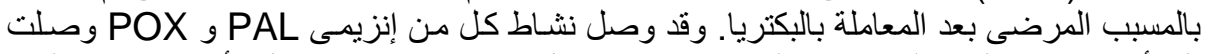

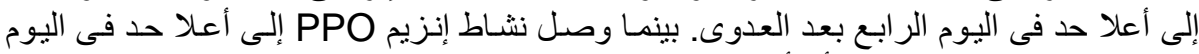

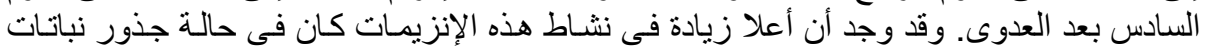

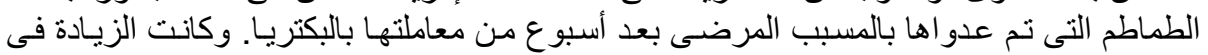

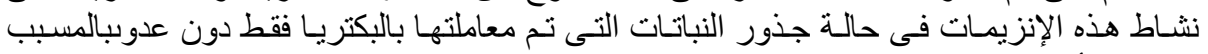

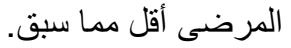

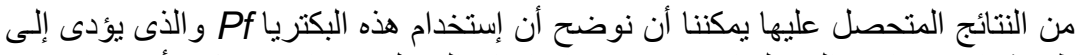

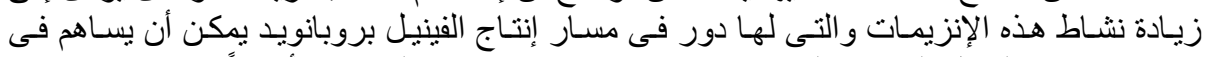

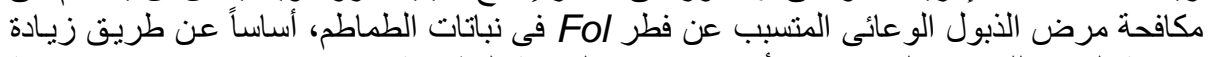

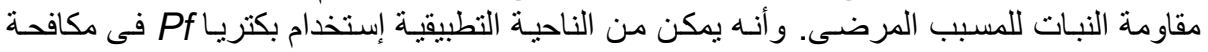

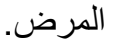


J. Agric. Sci. Mansoura Univ., 33 (6), June, 2008 